RESIDENT

\& FELLOW

SECTION

Section Editor

Mitchell S.V. Elkind,

MD, MS
Child Neurology:

\section{Hereditary spastic paraplegia in children}

S.T. de Bot, MD

B.P.C. van de

Warrenburg, MD,

$\mathrm{PhD}$

H.P.H. Kremer,

$\mathrm{MD}, \mathrm{PhD}$

M.A.A.P. Willemsen,

$\mathrm{MD}, \mathrm{PhD}$

Address correspondence and reprint requests to Dr. S.T. de Bot, Radboud University Nijmegen Medical Centre, Department of Neurology, PO Box 9101, 6500 HB, Nijmegen, the Netherlands

ST.Bot@neuro.umcn.nl
Because the medical literature on hereditary spastic paraplegia (HSP) is dominated by descriptions of adult case series, there is less emphasis on the genetic evaluation in suspected pediatric cases of HSP. The differential diagnosis of progressive spastic paraplegia strongly depends on the age at onset, as well as the accompanying clinical features, possible abnormalities on MRI, and family history. In order to develop a rational diagnostic strategy for pediatric HSP cases, we performed a literature search focusing on presenting signs and symptoms, age at onset, and genotype. We present a case of a young boy with a REEP1 (SPG31) mutation.

CASE REPORT A 4-year-old boy presented with progressive walking difficulties from the time he started walking at the age of 12 to 13 months. His family history was significant for minimal gait abnormalities with onset after age 35 , occurring in the patient's mother, maternal grandfather, and maternal aunt; none of them had ever sought medical attention. Neurologic examination revealed a mildly spastic gait and marked lower limb hyperreflexia with bilateral Babinski signs present. Vibration perception was reduced at the ankles. Neurologic examination of the patient's mother and maternal aunt revealed subtle gait abnormalities with bilateral Babinski signs present.

MRI of the brain and spinal cord and general metabolic screening revealed no abnormalities. Diagnostic genetic testing in both the patient and his mother revealed a pathogenic mutation (c.417 + 1 $\mathrm{G}>\mathrm{T}$ ) in REEP1 (SPG31) which causes a pure HSP. Mutations in ATL1 (SPG3A) and SPAST (SPG4) had previously been excluded.

DISCUSSION HSP is a genetically and clinically heterogeneous group of disorders in which the main clinical feature is progressive lower limb spasticity secondary to pyramidal tract dysfunction. HSP is classified as pure if neurologic signs are limited to the lower limbs (although urinary urgency and mild impairment of vibration perception in the distal lower extremities may occur). In contrast, complicated forms of HSP display additional neurologic and MRI abnormalities such as ataxia, more significant peripheral neuropathy, mental retardation, or a thin corpus callosum. HSP may be inherited as an autosomal dominant, autosomal recessive, or X-linked disease. Over 40 loci and nearly 20 genes have already been identified. ${ }^{1}$ Autosomal dominant transmission is observed in $70 \%$ to $80 \%$ of all cases and typically results in pure HSP. ${ }^{2}$

Spastic paraplegia is a common problem in the daily practice of pediatric neurologists, generally caused by acquired brain disorders such as perinatal asphyxia or infections early in life resulting in cerebral palsy. In addition, there is a long list of more rare disorders to consider when confronted with spastic paraplegia including structural, infectious, demyelinating, and metabolic disorders (table). ${ }^{3}$ Only in a small minority of cases does HSP underlie the spastic syndrome. Many patients with childhood-onset HSP are mistakenly diagnosed with cerebral palsy. ${ }^{4,5}$ In children with spastic paraplegia in whom no acquired cause can be identified, HSP should be considered. A positive family history aids with the diagnosis. Our case illustrates the importance of neurologic examination of family members who may be mildly affected.

Since the medical literature on HSP is dominated by adult case series, it is difficult to decide how the genetic evaluation should be structured when a child is suspected to have HSP. In order to develop a rational diagnostic strategy for HSP in children, we per-

\title{
GLOSSARY
}

ATL1 = atlastin (GTPase) 1; BSCL2 = Berardinelli-Seip congenital lipodystrophy 2 (seipin); KIF5A = kinesin family member $5 A ; L 1 C A M=L 1$ cell adhesion molecule; NIPA1 = nonimprinted in Prader-Willi/Angelman syndrome region protein 1; PLP1 = proteolipid protein 1; REEP1 = receptor expression-enhancing protein 1; SPAST = spastin; SPG = spastic paraplegia gene; ZFYVE26 = zinc finger FYVE domain-containing protein 26 (spastizin).

From the Departments of Neurology (S.T.d.B., B.P.C.v.d.W.) and Paediatric Neurology (M.A.A.P.W.), Donders Centre for Brain, Cognition, and Behaviour, Radboud University Nijmegen Medical Centre, Nijmegen; and Department Of Neurology (H.P.H.K.), University Medical Centre Groningen, Groningen, the Netherlands.

Disclosure: Author disclosures are provided at the end of the article. 


\begin{tabular}{|c|c|c|}
\hline Abnormalities on MRI & $\begin{array}{l}\text { Differential diagnosis of spastic paraplegia with additional } \\
\text { abnormalities on MRI of the brain }\end{array}$ & HSPs \\
\hline Leukoencephalopathy & $\begin{array}{l}\text { Many neurometabolic and other hereditary white matter disorders } \\
\text { with characteristic MRI pattern, like Krabbe disease, Alexander } \\
\text { disease, X-linked adrenoleukodystrophy, vanishing white matter; } \\
\text { inflammatory disorders like multiple sclerosis, acute disseminated } \\
\text { encephalomyelitis, neuromyelitis optica }\end{array}$ & $\begin{array}{l}\text { SPG4 (some), SPG11, } \\
\text { SPG15, SPG21 }\end{array}$ \\
\hline Thin corpus callosum & Thin corpus callosum + epilepsy, Andermann syndrome & $\begin{array}{l}\text { SPG1, SPG4 (some), } \\
\text { SPG11, SPG15, } \\
\text { SPG21, SPG32, }\end{array}$ \\
\hline Cerebellar atrophy & See cerebellar ataxia (below) & SPG7 \\
\hline Additional clinical features & $\begin{array}{l}\text { Differential diagnosis of spastic paraplegia with additional } \\
\text { clinical features }\end{array}$ & HSPs \\
\hline Mental retardation & $\begin{array}{l}\text { Many neurometabolic or neurogenetic disorders; sometimes } \\
\text { recognizable based on MRI abnormalities (see top of table) or } \\
\text { further additional features (see below) }\end{array}$ & $\begin{array}{l}\text { SPG1, SPG2, SPG11, } \\
\text { SPG14, SPG15, } \\
\text { SPG16, SPG20, } \\
\text { SPG21, SPG23, } \\
\text { SPG27, SPG32, } \\
\text { SPG35 }\end{array}$ \\
\hline Dysmorphisms & $\begin{array}{l}\text { Andermann syndrome, hydrocephalus due to congenital stenosis } \\
\text { of aqueduct of Sylvius }\end{array}$ & SPG1, SPG23 \\
\hline Optic atrophy & $\begin{array}{l}\text { Cobalamin C disease, biotinidase deficiency, cerebral folate } \\
\text { deficiency, SPOAN, ARSACS, type III 3-methylglutaconic aciduria }\end{array}$ & SPG7 \\
\hline Retinopathy & $\begin{array}{l}\text { Cobalamin C disease, Sjögren-Larsson syndrome, } \\
\text { homocarnosinosis, abetalipoproteinemia }\end{array}$ & SPG15 \\
\hline Cataract & $\begin{array}{l}\text { Cerebrotendinous xanthomatosis, } \alpha \text {-methyl-CoA racemase } \\
\text { deficiency }\end{array}$ & SPG9 \\
\hline Hearing loss/deafness & Biotinidase deficiency, cerebral folate deficiency & SPG29 \\
\hline Neuropathy/amyotrophy & $\begin{array}{l}\text { dHMN, HMSN V, cerebrotendinous xanthomatosis, cobalamin C } \\
\text { disease, MTHFR deficiency, metachromatic leukodystrophy, } \\
\text { Krabbe disease, adrenomyeloneuropathy, polyglucosan body } \\
\text { disease, } \alpha \text {-methyl-CoA racemase deficiency, biotinidase } \\
\text { deficiency, abetalipoproteinemia (posterior column), homocysteine } \\
\text { remethylation defects, SPOAN, ARSACS, Andermann syndrome }\end{array}$ & $\begin{array}{l}\text { SPG7, SPG9, SPG10, } \\
\text { SPG11, SPG14, } \\
\text { SPG17, SPG20, } \\
\text { SPG27, SPG38, } \\
\text { SPG39 }\end{array}$ \\
\hline Cerebellar ataxia & $\begin{array}{l}\text { Atypical Friedreich ataxia, cerebrotendinous xanthomatosis, triple } \\
\text { H syndrome, cerebral folate deficiency, metachromatic } \\
\text { leukodystrophy, SAX1, SAX2, ARSACS, ARSAL, Type III 3- } \\
\text { methylglutaconic aciduria, Alexander disease }\end{array}$ & $\begin{array}{l}\text { SPG7, SPG15, } \\
\text { SPG20, SPG21, } \\
\text { SPG27 }\end{array}$ \\
\hline $\begin{array}{l}\text { Extrapyramidal signs/diurnal } \\
\text { fluctuations }\end{array}$ & $\begin{array}{l}\text { Dopamine synthesis defects and cerebral folate deficiency } \\
\text { (dystonia), amyotrophic dystonic paraplegia (dystonia), } \\
\text { polyglucosan body disease, phenylketonuria and } \\
\text { cerebrotendinous xanthomatosis (parkinsonism), dopa-responsive } \\
\text { dystonia (diurnal fluctuations) }\end{array}$ & $\begin{array}{l}\text { SPG21, SPG23 } \\
\text { (tremor) }\end{array}$ \\
\hline Epilepsy & $\begin{array}{l}\text { Dopamine synthesis defects, } \alpha \text {-methyl-CoA racemase deficiency, } \\
\text { triple } \mathrm{H} \text { syndrome, metachromatic leukodystrophy, } \\
\text { cerebrotendinous xanthomatosis, arginase deficiency, cerebral } \\
\text { folate deficiency, thin corpus callosum + epilepsy, Alexander } \\
\text { disease }\end{array}$ & SPG2, SPG35 \\
\hline Cutaneous signs & $\begin{array}{l}\text { Cerebrotendinous xanthomatosis (xanthomas), biotinidase } \\
\text { deficiency (alopecia, dermatitis), Sjögren-Larsson (ichthyosis), } \\
\text { adrenoleukodystrophy/adrenomyeloneuropathy (melanoderma) }\end{array}$ & $\begin{array}{l}\text { SPG23 (pigmentary } \\
\text { abnormalities) }\end{array}$ \\
\hline $\begin{array}{l}\text { Episodes of confusion, nausea/ } \\
\text { vomiting, or diarrhea }\end{array}$ & $\begin{array}{l}\text { Cobalamin C disease, MTHFR deficiency, triple } \mathrm{H} \text {, arginase } \\
\text { deficiency, cerebrotendinous xanthomatosis (chronic diarrhea), } \\
\text { adrenal insufficiency (adrenomyeloneuropathy, } \\
\text { adrenoleukodystrophy), abetalipoproteinemia (diarrhea), } \\
\text { homocysteine remethylation defects (confusion) }\end{array}$ & $\begin{array}{l}\text { SPG9 } \\
\text { (gastroesophageal } \\
\text { reflux), SPG29 } \\
\text { (hiatus hernia, } \\
\text { hyperbilirubinemia) }\end{array}$ \\
\hline
\end{tabular}

Abbreviations: ARSACS = autosomal recessive spastic ataxia of Charlevoix-Saguenay; $A R S A L=$ autosomal recessive spastic ataxia with leukoencephalopathy; $\mathrm{dHMN}=$ distal hereditary motor neuropathy; HMSN = hereditary motor and sensory neuropathy; HSP = hereditary spastic paraplegia; MTHFR = 5,10-methylenetetrahydrofolate deficiency; SAX1/ SAX2 = spastic ataxia; SPG1 = L1CAM; SPG2 = PLP1; SPG4 = SPAST; SPG10 = KIF5A; SPG15 = ZFYVE26; SPG17 = BSCL2; SPOAN = spastic paraplegia, optic atrophy, and neuropathy; triple $\mathrm{H}$ syndrome = hyperornithinemiahyperammonemia-homocitrullinuria syndrome.

formed a literature search focusing on presenting signs and symptoms, age at symptom onset, and genotype. We also share some of our personal experiences from a clinicgenetic database, as our institution has served as a tertiary referral center for Dutch HSP patients for over 2 decades.
Characteristics. In the medical literature, symptom onset before age 18 has been documented in many HSP cases, particularly in the complicated forms, which show a clear overlap with many metabolic disorders and leukodystrophies. In a series of 23 
children with HSP, 15 of 23 (65\%) were reported to have a complicated (mostly recessively inherited) HSP, compared to 8 of $23(35 \%)$ with a pure HSP. ${ }^{6}$

In our HSP database, an early age at symptom onset (prior to age 18) was found in 72 of 175 (41\%) patients, with a heterogeneous genetic background: 47 of 72 (65\%) autosomal dominant cases, 12 of 72 (17\%) autosomal recessive cases, and 13 of 72 (18\%) sporadic cases. Gait difficulties were the presenting symptom in $81 \%$, with a mean age of 8 years. A complicated phenotype was present in $25 \%$. Of these 72 early-onset HSP patients, at least $20(28 \%)$ had presented in childhood to a pediatrician or pediatric neurologist.

Prior reviews have provided in-depth descriptions and overviews of all known HSP forms. ${ }^{1,2}$ In this article, we focus on the most prevalent ( $>5$ families described) forms of HSP with a possible childhood onset.

Autosomal dominant pure HSP. ATL1 (SPG3A). This is a pure form of HSP, comparable to SPG4, and almost never starts after age 20 years. It is the most frequent cause of HSP (twice as frequent as SPAST), with onset before age 10 years. ${ }^{7}$ Therefore, ATL1, which encodes atlastin (a dynaminlike GTPase), is the first candidate gene that should be tested in patients with a suspected pure autosomal dominant or sporadic HSP with symptom onset before age $10 .^{2}$

SPAST (SPG4). SPG4 is the most prevalent, mostly pure form of HSP with a variable age at onset, varying from infancy through over 70 years of age. SPAST encodes spastin with microtubule-severing activity, necessary for axonal transport. In a large study of 172 SPAST patients, approximately 30\% had an age at onset before 20 years. ${ }^{8}$ In our SPAST cohort, comparable figures were found, with walking difficulties presenting at a mean age of 7.5 years (range 1-18 years) in this young-onset group. Onset in infancy is unusual. After the description of $5 \mathrm{pa}$ tients from 1 family, ${ }^{5}$ we identified an additional 5 patients from 4 families with symptom onset in infancy. Until that point, such a young onset had been described only in association with co-dominant mutations (genetic modifiers) in the SPAST gene. Therefore, SPAST is the second candidate gene that should be tested in patients with a pure HSP with symptom onset before age 10, after ATL1. With an onset of symptoms between 10 and 20 years, both genes should be tested.

NIPA1 (SPG6), KIF5A (SPG10), and SPG12. SPG6 causes a pure HSP, occasionally with a childhood onset, but more commonly with onset of symptoms in the late teenage to early adult years. ${ }^{9}$ SPG10 and
SPG12 both lead to an early-onset pure HSP. All 3 are described in fewer than 10 families. ${ }^{1}$

REEP1 (SPG31). SPG31, a pure form of HSP, shows a variable age at onset, with an onset before 20 years in $71 \%$ of cases. ${ }^{10}$ REEP 1 encodes the mitochondrial protein receptor expression-enhancing protein 1. REEP1 mutations were found in $8.2 \%$ of pure autosomal dominant HSP patients (of all ages), in whom ATL1 or SPAST mutations had been excluded. ${ }^{1}$

We encountered 5 SPG31 patients who presented before age 18 years, with gait abnormalities and foot deformities at a mean age of 4 years. REEP 1 mutations can cause a pure HSP in children, but should only be tested after SPAST and ATL1 mutations have been ruled out.

Complicated forms of HSP. L1CAM (SPG1) and PLP1 (SPG2). These are both X-linked and complicated forms of HSP, which may be tested in boys with mental retardation and other clinical features. ${ }^{1,2}$

SPG7. SPG7, an autosomal recessive HSP, causes a spastic paraplegia in combination with cerebellar ataxia, cerebellar atrophy, optic atrophy, and peripheral neuropathy. Age at onset varies from 10 to 42 years in the literature, but mostly adult cases have been reported.

SPG11 and ZFYVE26 (SPG15). SPG11 is the most frequent form of autosomal recessive HSP with onset typically in childhood (age range 1.5-21 years). It is characterized by a thin corpus callosum, mild leukoencephalopathy, mild mental retardation, and peripheral neuropathy. A comparable autosomal recessive syndrome is SPG15 (Kjellin syndrome), with additional cerebellar signs, maculopathy, and onset between 5 and 19 years.

BSCL2 (SPG17). SPG17 (Silver syndrome) has a variable age at onset. Distal amyotrophy affecting upper extremities more than lower extremities accompanies the spastic paraplegia. Inheritance is autosomal dominant.

Four SPG17 patients in our cohort, with onset between 10 and 16 years, presented with weakness of the upper extremities greater than in the lower extremities, and 3 of the 4 had foot or hand deformities.

Genetic testing in children. A formal diagnosis provides a prognosis, prevents additional burdensome and potentially costly diagnostic evaluation, may facilitate the prevention of complications, and allows for potential inclusion in clinical trials. In addition, a genetic diagnosis allows for genetic counseling with regard to the recurrence risk within the family. Ethical, social, and financial considerations, as well as written or verbal informed consent from the parents, according to established guidelines, are necessary before genetic testing in children. 
Figure Diagnostic flow chart of hereditary spastic paraplegia in children

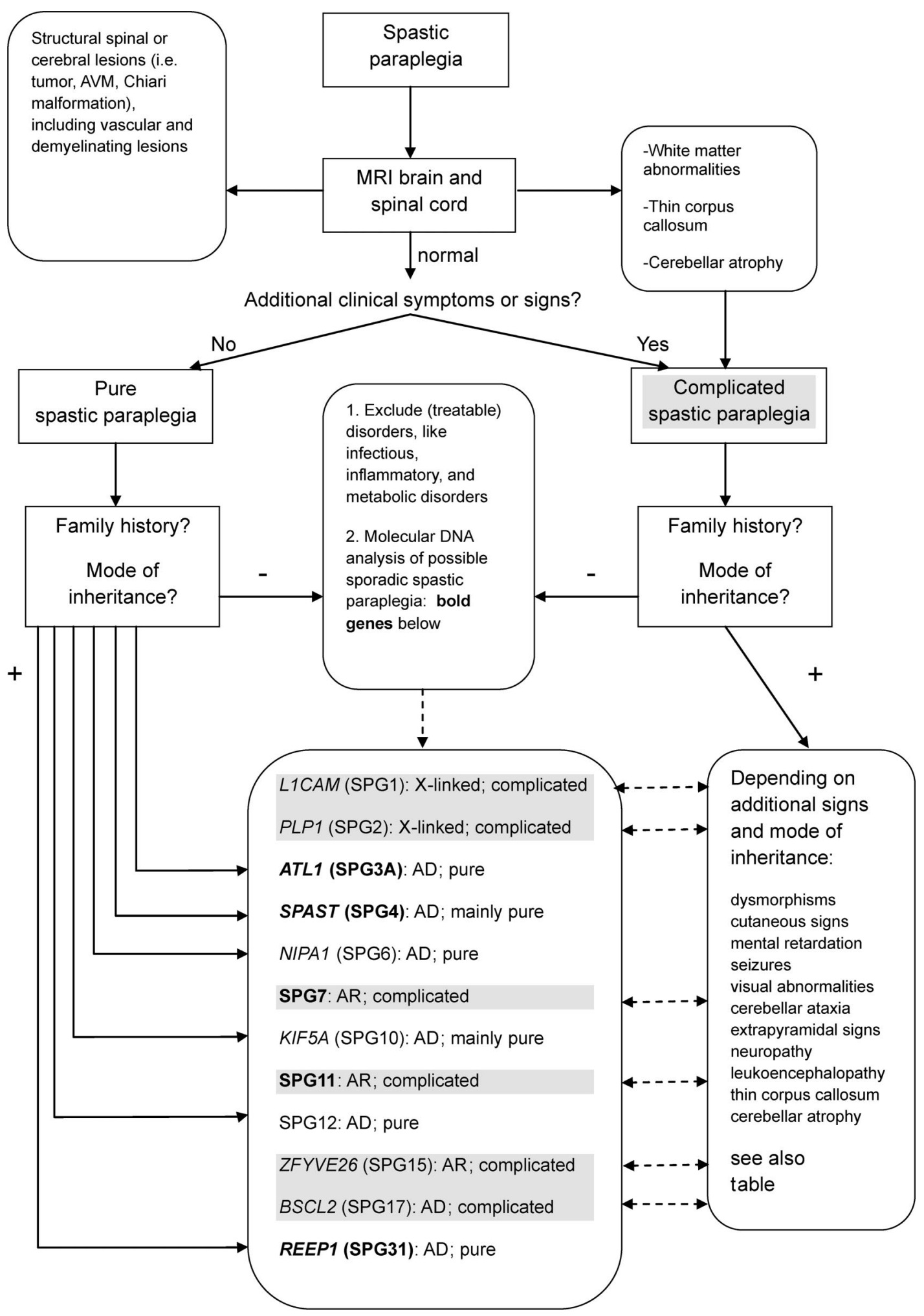

The combination of pure or complicated (gray) and the mode of inheritance will help to select the appropriate DNA tests. $\mathrm{AD}=$ autosomal dominant; $\mathrm{AR}=$ autosomal recessive; $\mathrm{AVM}=$ arteriovenous malformation.

Diagnostic approach. When confronted with a child with a pure spastic paraplegia, a thorough family history (of at least 3 generations) is essential. After neurologic examination of the child and the parents, structural lesions and white matter disorders need to be excluded by performing MRI of the brain, with transverse T1, T2, 
and sagittal T1 images, and of the entire spinal cord. A positive family history or examination facilitates direct diagnostic genetic testing (figure).

In a pure, autosomal dominant HSP, ATL1 (SPG3A) and SPAST (SPG4) mutation analysis would be the first tests of choice. If negative, REEP1 (SPG31) could be tested subsequently. In case of a negative family history or examination, ophthalmologic examination, CSF analysis, and metabolic screening should be considered, primarily to look for conditions with disease-modifying therapies available. Finally, a trial of levodopa may be considered, since a dystonic gait and striatal toes as part of a dopa-responsive dystonia syndrome could be mistaken for spastic paraplegia. ${ }^{3}$ If these investigations are negative, ATL1 and SPAST mutation analysis should be considered because sporadic cases (due to de novo mutations and incomplete penetrance) have been described in these HSP forms. ${ }^{4,5}$

When confronted with a child with a complicated spastic paraplegia, the accompanying signs and symptoms will lead to a differential diagnosis and the required specific diagnostic evaluation (table). ${ }^{1,2}$

\section{DISCLOSURE}

Dr. de Bot reports no disclosures. Dr. van de Warrenburg has served as Movement Disorders Section Editor for Health Direct Neurology (Reed Elsevier) and receives/has received research support from Ipsen Pharmaceuticals, the European Union (FP6 program), the Prinses Beatrix Fonds, and the Dutch Brain Foundation. Dr. Kremer serves on scientific advisory boards for the Hersenstichting Nederland and Prinses Beatrix Fonds; has received speaker honoraria from Pfizer Inc.; and receives research support from the Radboud University Nijmegen Medical Centre, the Netherlands. Dr. Willemsen reports no disclosures.

\section{REFERENCES}

1. Salinas S, Proukakis C, Crosby A, Warner TT. Hereditary spastic paraplegia: clinical features and pathogenetic mechanisms. Lancet Neurol 2008;7:1127-1138.

2. Depienne C, Stevanin G, Brice A, Durr A. Hereditary spastic paraplegias: an update. Curr Opin Neurol 2007;20: 674-680

3. Sedel F, Fontaine B, Saudubray JM, Lyon-Caen O. Hereditary spastic paraparesis in adults associated with inborn errors of metabolism: a diagnostic approach. J Inherit Metab Dis 2007;30:855-864.

4. Rainier S, Sher C, Reish O, Thomas D, Fink JK. De novo occurrence of novel SPG3A/atlastin mutation presenting as cerebral palsy. Arch Neurol 2006;63:445-447.

5. Blair MA, Riddle ME, Wells JF, Breviu BA, Hedera P. Infantile onset of hereditary spastic paraplegia poorly predicts the genotype. Pediatr Neurol 2007;36:382-386.

6. Appleton RE, Farrell K, Dunn HG. 'Pure' and 'complicated' forms of hereditary spastic paraplegia presenting in childhood. Dev Med Child Neurol 1991;33:304-312.

7. Namekawa M, Ribai P, Nelson I, et al. SPG3A is the most frequent cause of hereditary spastic paraplegia with onset before age 10 years. Neurology 2006;10:66:112-114.

8. Fonknechten N, Mavel D, Byrne P, et al. Spectrum of SPG4 mutations in autosomal dominant spastic paraplegia. Hum Mol Genet 2000;1:9:637-644.

9. Bien-Willner R, Sambuughin N, Holley H, Bodensteiner J, Sivakumar K. Childhood-onset spastic paraplegia with NIPAL gene mutation. J Child Neurol 2006;21:974-977.

10. Beetz C, Schule R, Deconinck T, et al. REEP1 mutation spectrum and genotype/phenotype correlation in hereditary spastic paraplegia type 31 . Brain 2008;131:10781086. 


\section{Neurology}

\section{Child Neurology: Hereditary spastic paraplegia in children \\ S.T. de Bot, B.P.C. van de Warrenburg, H.P.H. Kremer, et al. Neurology 2010;75;e75-e79 \\ DOI 10.1212/WNL.0b013e3181fc2776}

\section{This information is current as of November 8,2010}

\section{Updated Information \& Services}

References

Citations

Subspecialty Collections

Permissions \& Licensing

Reprints including high resolution figures, can be found at: http://n.neurology.org/content/75/19/e75.full

This article cites 10 articles, 0 of which you can access for free at: http://n.neurology.org/content/75/19/e75.full\#ref-list-1

This article has been cited by 1 HighWire-hosted articles: http://n.neurology.org/content/75/19/e75.full\#\#otherarticles

This article, along with others on similar topics, appears in the following collection(s):

\section{All Genetics}

http://n.neurology.org/cgi/collection/all_genetics

All Pediatric

http://n.neurology.org/cgi/collection/all_pediatric

All Spinal Cord

http://n.neurology.org/cgi/collection/all_spinal_cord Spastic paraplegia

http://n.neurology.org/cgi/collection/spastic_paraplegia

Information about reproducing this article in parts (figures,tables) or in its entirety can be found online at:

http://www.neurology.org/about/about_the_journal\#permissions

Information about ordering reprints can be found online:

http://n.neurology.org/subscribers/advertise

Neurology ${ }^{\circledR}$ is the official journal of the American Academy of Neurology. Published continuously since 1951, it is now a weekly with 48 issues per year. Copyright Copyright (? 2010 by AAN Enterprises, Inc.. All rights reserved. Print ISSN: 0028-3878. Online ISSN: 1526-632X.

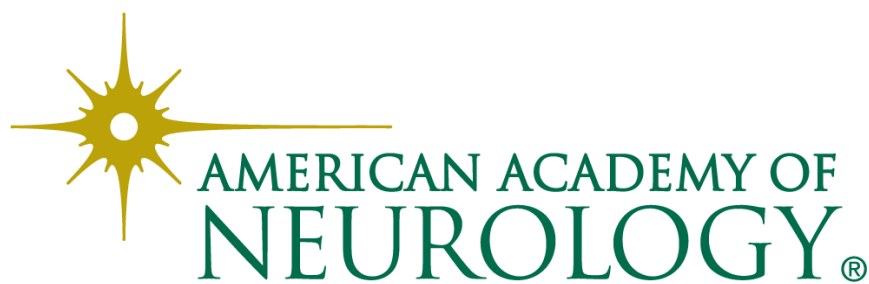

